\title{
Oksana Kuzmenko
}

(Uniwersytet Narodowy „Akademia Ostrogska”, Ostróg - Ukraina

- Uniwersytet Marii Curie-Skłodowskiej w Lublinie, Lublin - Polska)

\section{КІНО ЯК ІНСТРУМЕНТ ФОРМУВАННЯ НАЦИОНААЬНОЇ ІАЕНТИЧНОСТІ. УКРАЇНСЬКИЙ КОНТЕКСТ}

\author{
Люди приходять в кіно для того, \\ щоб розділити одну і ту саму мрію. \\ Бернардо Бертолуччі
}

Повсякчас людина знаходиться в пошуку власної суті, ставлячи собі запитання: „Х Хто я?”. Відповідь на це запитання стає фундаментом до творення власної ідентичності. Сучасність продукує нові виклики та відкриває незвідані ніші, в яких людина може себе оцінити. Разом із тим, створює інструменти до формування таких оцінок.

Кінець дев' ятнадцятого - початок двадцятого сторіччя - це період актуалізації питання націоналізму і, відповідно, національної ідентичності. Процеси ототожнення людиною себе із певною нацією та її культурними цінностями набувають усе більшої ваги. Національна складова, як зазначає Ентоні Сміт, спромоглася об'єднати релігійно розірвані спільноти на новій, політичній основі ${ }^{1}$. Вона і дотепер залишається однією з базових пунктів як різноманітних політичних доктрин, так і політики держави у сфері національної безпеки.

Ідентичність, насамперед національна, формується під впливом процесів культурації (участі особи в символічній культурі: традиціях, віруваннях, мистецтві й історії) і соціалізації (засвоєння певної системи знань, норм і цінностей, поведінки в певному суспільстві) ${ }^{2}$. Якщо культурація - це в основному трансформація цінностей із покоління в покоління, то соціалізація заснована на засвоєнні сучасних моделей, у масових масштабах трансляторами яких виступають мас-медіа.

1 Е. Сміт, Національна ідентичність, Київ 1994, с. 10-27, http://litopys.org.ua/smith/ smi02.htm (20.11.2011)

2 Див.: A. Kłosowska, Socjologia kultury, Warszawa 1983, [в:] P. Boski, O byciu Polakiem w Ojczyźnie. Tożsamość a odmienność kulturowa, Warszawa 1992. 
Відомий теоретик Денніс Макквейл ${ }^{3}$ перераховує основні засоби масової інформації, серед яких значну роль приділено кінематографу. Такі його характеристики, як розважальний характер, універсальна привабливість та фотографічний реалізм, надають значну перевагу перед іншими ЗМІ в подачі інформації, а навіть більше - пропаганді. Адже процес перегляду фільму - це не тільки пізнавання, але й завжди розвага. Недарма величезну роль у просуванні власних ідей убачали як фашисти, так і комуністи. Найважливіший із усіх видів мистецтва, за Володимиром Леніним, і один із найпотужніших інструментів впливу є саме кіно.

Роль кіно в людському світосприйнятті описують психоаналітична та когнітивна теорії фільму. Перша характеризує роль несвідомого у сприйманні стрічки, коли глядач зачаровано дивиться на екран подібно до малої дитини, що дивиться в дзеркало, відчуваючи власну всесильність (апелюючи до Стадіï дзеркала Жака Лакан). При чому

перегляд фільмів - уявна приємність, під час якої глядач уходить у поле дії фільму і стає податливий на ідеологічні навіювання4 .

За словами одного з найбільш яскравих представників сучасного психоаналізу Славоя Жижека,

кіно - найбільш збочений вид мистецтва, воно не дає вам того, чого ви бажаєте, воно говорить вам як бажати 5

Якщо в основі психоаналітичної теорії лежить ідея ідентифікації себе з тим, що відбувається на екрані, а панівна роль відводиться несвідомим чинникам впливу на особистість, то в основі когнітивної теорії - ідея пізнання, коли глядач є свідомим і раціональним реціпієнтом інформації. За умови розуміння того, що відбувається на екрані, він може вчитись певним моделям поведінки, перейматися відповідними ідеями і визначеним способом розв'язувати проблеми.

3 огляду на досліди представників когнітивної теорії, в поле зору нашого дослідження входять лише кінопродукція ігрового популярного жанру, що апріорі зорієнтована на розуміння масовою аудиторією свого змісту.

Перед незалежною Україною після розпаду Радянського Союзу постало важливе завдання творення нової ідентичності ії громадян.

3 Див.: McQuail, Teoria komunikowania masowego, Warszawa 2007.

${ }^{4}$ M. Sokołowski, (R)ewolucja w komunikowaniu. Wprowadzenie do medioznawstwa, Warszawa 2010, c. 101.

5 S. Žižek, The Pervert's Guide to Cinema (documentary film directed and produced by Sophie Fiennes - 2006). 
За умови, що процес творення ідентичності - це процес ототожнення себе 3 певним культурним надбанням і водночас відокремлення від „чужого”, Україна стає перед складним питанням, адже успадковує культуру не лише власне українську, а й радянську. Ті, своєю чергою, дуже часто мають амбівалентні цінності. Радянська ідентичність, до слова, була штучно сформована засобами масової інформації і пропаганди, кіно серед яких відігравало одну з найважливіших ролей, тому саме йому варто приділяти одну з основних ролей в осмисленні процесів формування ідентичності.

Сучасні соціологічні дослідження підтверджують важливу роль кіно в сучасному українському суспільстві. Так, відповідаючи на питання, оприлюднене в новинах одного 3 центральних українських каналів дослідження, „Що для вас є головним носієм моральних цінностей?"6, називають сім'ю, церкву, школу й кінематограф із літературою. Це достойний аргумент того, що кіно залишається одним із інструментів виховання та зберігання цінностей.

Закон України про кінематографію, що є основним документом на державному рівні, регулює діяльність цієї сфери, визначає національне кіно так:

Національний фільм - створений суб'єктами кінематографії України фільм, виробництво якого здійснено в Україні та авторське право чи право власності на який повністю або частково належить суб'єктам кінематографії України, а також основна (базова) версія мовної частини звукового ряду якого створена українською мовою ${ }^{7}$.

Додамо, що основними принципами кінематографії вважають сприяння розвитку „національної свідомості, патріотичних почуттів [...] громадян"8. В Україні налічується п'ять державних кіностудій - Національна кіностудія художніх фільмів імені О.П. Довженка, Одеська кіностудія художніх фільмів, Національна кінематика України, Українська кіностудія анімаційних фільмів, Українська студія хронікально-документальних фільмів, понад 20 кіностудій недержавної форми власності та українсько-російське підприємство Закрите акціонерне товариство „Ялтинська кіностудія”. Серед них особливий інтерес для нас становлять перші дві, оскільки їх продукція - державне ігрове кіно. За інформацією, поданою на офіційних сайтах кіностудій у період з 2000 року і донині, Кіностудією ім. О.П. Дов-

6 Українці розчарувалися в державі і вірять тільки в сім'ю, http://tsn.ua/ukrayina/ ukrayinci-rozcharuvalisya-v-derzhavi-i-viryat-tilki-v-sim-yu.html (17.11.2011).

7 Див.: Закон України про кінематографію. („Відомості Верховної Ради України” (ВВР), 1998, № 22, ст. 114), http://zakon.rada.gov.ua/cgi-bin/laws/main.cgi?nreg=9\%2F98-\%E2\% F0 (17.11.2011).

8 Там само. 
женка було знято 37 фільмів, а Одеською - 28. Відсутність в описах більшої частини фільмів додаткової інформації на сайті Кіностудії ім. О.П. Довженка не дало змоги розділити художні фільми від документальних і короткометражних, до того ж, очевидним є той факт, що інформація на сайті не поновлювалась із 2009 року.

Чи не найголовнішою проблемою української кінематографії $є$ проблема, яку видатний польський фільмознавець Аліція Хельман окреслила так:

Загроза народжується у сфері контактів із фільмом. [...] Подібним фактом, цього разу зі сфери продукції, $є$ факт творення фільмів (наприклад на теренах колишнього Радянського Союзу), яких ніхто не дивиться, і не тому, що не хоче, а тому, що вони не творяться для того, щоб їх хтось дивився9.

Інформаційний простір України переповнений не фільмами власної продукції (що „не творяться щоб їх хтось дивився”), а фільмами іноземними, що не можуть бути трансляторами національної української культури. Подекуди такі стрічки навіть, навпаки, містять ідеї, що суперечать національним цінностям.

Ми спробували оцінити стан присутнього в Україні сучасного масового ігрового кіно як інструменту формування національної ідентичності за репрезентованістю в ньому цінностей трьох сфер - релігії, мови та історії.

На думку Ентоні Сміта,

[...] етнічна та релігійна ідентичність мають багато спільних рис. Обидві вони походять від схожих культурних критеріїв класифікації. Вони часто перекривають і посилюють одна одну. Поодинці або разом вони можуть мобілізувати й підтримувати міцні спільноти ${ }^{10}$.

Ситуація в Україні не дає змоги об'єднати всю українську націю за релігійним чинником, оскільки там немає однієї домінуючої релігії. За даними досліджень Центру Разумкова ${ }^{11}$, що проведені в 2006 році, найбільш численною є група, що зараховує себе до Української православної церкви (Київського патріархату) 14,9\% (це 29,4\% 3 тих, хто зараховує себе до відповідної конфесії чи церкви). Наступну за кількістю становлять представники Української православної церкви (Московського патріархату) 10,9\% (29,4\% відповідно), далі виокрмлюємо Українську греко-католицьку церкву - 5,3\% (14,1\% відпо-

${ }^{9}$ A. Helman, Sposoby uprawiania teorii filmu. Prędkość i przyjemność. Kino i telewizja w dobie symulacji elektronicznej, Kielce 1994, c. 17.

${ }^{10}$ Е. Сміт, Національна ідентичність, http://litopys.org.ua/smith/smi.htm (20.11.2011).

${ }_{11}$ Центр Разумкова, Віруючим якої церкви, конфесії Ви себе въажаєте?, http:// razumkov. org.ua/ukr/poll.php?poll_id=300 (10.10.2011). 
відно). До того ж, великими є громади Української автокефальної церкви, Християнських протестантських церков, Римо-католицької церкви, ісламу, іудаїзму і буддизму.

Складна релігійна ситуація підсилюється конфронтацією конфесій усередині православної церкви, протистоянням УПЦ КП і УПЦ МП. За словами професора Василя Баранівського,

[...] кожна релігія, конфесія впроваджує в українське середовище певну культуру, мову, традиції, звичаї, національно-політичні орієнтації. Так, УПЦ Московського патріархату, згідно зі своєю філософією, спрямована на Москву та принизливу підлеглість їй, особливості ії вчення та культу мають російське „забарвлення". А тому УПЦ МП прагне виховати у відповідному дусі населення України. [...] відродження українського православ'я - це не лише зміна назви православної церкви, але й їі глибока духовна i, зокрема, мовна переорієнтанція12.

Із поданих на офіційних сайтах державних кіностудій загальних списках з-посеред усіх фільмів, знятих від 2000 року, питання релігійної тематики та репрезентація релігійних персоналій відтворюються лише у двох, знятих студією ім. О.П. Довженка, - трилогія Таємниці Києво-Печерської Лаври (фільм режисера Миколи Ільїнського про святиню, що належить нині УПЦ МП) та Владика Андрей (фільм Олеся Янчука про єпископа УГКЦП). Перший фільм є документальним і в масовий прокат не виходив. Така кількість україномовних фільмів не становить гідної конкуренції російським фільмам про Російську православну церкву i iї уявних чи реальних представників. Це передусім такі фільми, як: Поп (Владимира Хотиненка), Цар і Ocmpib (Павла Лунгіна), Диво (Олександра Прошкіна). Разом із тим, існує низка масових фільмів із другорядними позитивними ролями православних священиків і православної віри. Серед них - Тарас Бульба (Владимира Бортка), 12 та Стомлені сонцем 2 (Никиты Михалкова) та безліч інших.

У питаннях формування релігійної ідентичності український кінематограф не займає чіткої позиції, відповідно, домінуючою $\epsilon$ роль російського кінематографу, що „лобіює” Російську Православну Церкву, інтереси якої дуже часто не збігаються із „відродженням українського православ' я" та формуванням цілісної української національної ідентичності.

Питання непересічної ролі мови в контексті національної ідентичності серед багатьох інших піднімає у своїх працях і видатний польський науковець Сжи Бартмінський. Він зауважує:

12 В. Баранівський, Діяльність УПЦ Московського патріархату як загроза украӥнській державності, http://www.anvou.org.ua/academy/herald_info/visnyk_75_4_11/visnyk_75_4_ 11_28-34.pdf (12.10.2011). 
У XVIII-XIX ст., коли домінуючим рухом у Європі став націоналізм, мова почала функціонувати як перший зовнішній знак групової ідентичності, оскільки це простежуємо сьогодні в багатьох регіонах світу13.

Питання функціонування, поширеності і розвитку української мови порушує у своїх численних працях український професор Лариса Масенко.

Асиміляція значної частини українського населення, що спричинила ослаблення національної самосвідомости українців, витіснення української мови російською у східних, південних і частково центральних областях України, передусім у великих промислових центрах, становить одну з головних перешкод у побудові національної держави, незалежної від колишньої імперської метрополії ${ }^{14}$,

- зауважує дослідниця. Стан української мови в контексті національної безпеки неодноразово порушуються як представниками української інтелігенції, наприклад, Ліною Костенко („Нації вмирають не від інфаркту. Спочатку їм відбирає мову"), так і представниками українського політикуму, наприклад Віктором Ющенком у статті В Україні іде „мовна війна"15.

Питання репрезентації мови в кінематографі $є$ надзвичайно важливим у контексті розгляду його як інструменту формування національної ідентичності. 3 двох кіностудій, що знімають ігрові фільми, лише Кіностудія ім. О.П. Довженка переважну більшість фільмів знімає українською мовою, тоді як переважна більшість фільмів, відзнятих в Одесі, - російськомовні. Проте, як було зазначено, проблема сучасного кінематографу здебільшого знаходиться в площині взаємоконтакту продукції і глядача. Більшість україномовних фільмів глядач так і не отримує. Частина стрічок у кращому разі осідає в рамках фестивалів. Так, наприклад, відоме видання „Телекритика” в рецензії на кінофестиваль „Молодість” пише, що національна студія імені О.П. Довженка „виробляє художні кінофільми, представляє їx і на фестивалі, і на кіноринку, але в якості товару свою продукцію не розглядає" 16.

Одним із найважливіших питань у цьому контексті є мовна політика держави, що, по суті, повинна захищати інтереси державної

${ }^{13} \mathrm{~J}$. Bartmiński, Jezzyk nośnikiem tożsamości narodowej i przejawem otwartości, [в:] Tożsamość polska i otwartość na inne społeczeństwa, red. L. Dyczewski, Lublin 1996, c. 41.

14 Л. Масенко, Мовна ситуація в Україні, http://www.ji.lviv.ua/n35texts/masenko-mov _syt.htm (10.10.2011).

15 В. Ющенко, Чия мова - того і влада, http://www.razom.org.ua/opinions/9678/ (10.10.2011).

16 А. Кокотюха, „Кіноринок Молодість” без ажіотажу та пафосу, http:// www.telekritika. ua/cinema/2008-10-29/41573 (10.10.2011). 
мови в умовах цієї складної ситуації. Міністерство культури України попри те, що вимагає обов' язкового субтитрування чи озвучення всіх іноземних фільмів, надає право дистриб'юторським компаніям:

[...] згідно з Постановою КМУ № 551 в умовах вільного ринку самостійно обирати мову дубляжу або озвучення, якщо роботи з дублювання або озвучення іноземної картини будуть виконані виключно на території України ${ }^{17}$.

Такий стан речей фактично жодним чином не сприяє розвитку української мови. При тому, що за даними всеукраїнського перепису населення 2001 р. 67,5\% українців уважають усе ж таки рідною українську мову, тоді коли російську $-29,6 \% 18$.

Питання інтерпретації історичних подій є одним із найбільш актуальних у контексті питання існування нації і формування національної ідентичності. Після розпаду Радянського Союзу з'явилась необхідність переоцінки багатьох історичних подій, що й демонструє українська історіографія цього періоду, а перед державою постало завдання надати можливість отримувати таку інформацію через мас-медіа, серед яких - кінематограф. Зауважимо, що формування національної ідентичності вимагає існування спільної ідеології, яку члени суспільства поділяють щодо усього історичного шляху українського народу. Особливу увагу слід було б приділити питанням, що замовчувались у радянському кінематографі або висвітлювались згідно радянської ідеології. Зокрема це такі, як: Княжа доба, Козацька держава, Національне відродження тощо

Одеська кіностудія фіксує лише декілька фільмів, що відображають історичну проблематику, причому майже всі торкаються тематики другої світової війни в такому ж ключі, як це робилося ще за радянських часів (військовий подвиг радянських воїнів). Серед таких фільмів можна назвати Сапери (військова драма про радянських саперів створена за підтримки Міністерства Культури України режисерами Борисом Щербаковим, Владимиром Щербаковим, Владимиром Кустовим), Сорокоп'ятка (Вячеслава Афоніна), Двоє і війна (Віталія Воробйова), Розвідники (військовий серіал про подальші „подвиги" радянських героїв після війни Олександра Замятіна) та інші. Фільми Сапери та Двоє і війна зняті спільно з російською компанією Сінебрідж-Кіно в період активного фінансування Російською Федерацією цієї кінокомпанії „на постачання товарів, вико-

17 Міністерство Культури України, До уваги представників 3мі!, http://mincult.kmu. gov.ua/mincult/uk/publish/article/225967 (12.10.2011).

18 Див.: O. Butsenko, Compendium of Cultural Policies and Trends in Europe, http://www.cultural policies.net/down/ukraine_ol_022011.pdf (12.10.2011). 
нання робіт і надання послуг для потреб Федерального агентства по культурі і кінематографії"19. Це є аргументом того, що українські кіностудії знімають частково за свій рахунок ідеологічно вигідне Росії кіно російською мовою.

Національна кіностудія ім. О.П. Довженка репрезентує низку фільмів на історичні теми, серед яких і ті, що порушують питання, „заборонені" в радянські часи. Можемо назвати фільми Братство (Станіслава Клименко про діяльність Кирило-Мифодіївского братства), Богдан-Зиновій Хмельницький (Миколи Мащенка), Молитва за Гетьмана Мазепу (Юрія Іллєнка), Мамай (Олеся Саніна), вище названий фільм Владика Андрей та Аттентат. Осіннє вбивство у Мюнхені (Олександра Янчука), Вальшнепи (Олександра Муратова), Дорога на Січ (Сергія Омельчука), а також День переможених (Валерія Ямбурського) та багато інших.

Головною персоною у творенні українських фільмів на історичну тематику є Олесь Янчук, який, окрім вищеназваних, відзняв низку фільмів (Голод 33, Нескорений, Залізна сотня) без залучення державних коштів. Цікавою в цьому контексті є постать Сергія Буковського. I хоча він знімає документальні, а не художні стрічки, та навколо них зосереджується увага світового суспільства (на жаль не масової української аудиторії). Це такі фільми, як Живі, Назви сbоє ім'я, Війна. Украӥнський рахунок.

Проте проблема, про яку йдеться, залишається: фільми у кращому разі демонструють на кінофестивалях, але їх не бачить масовий глядач. Причини цього полягають у недостатній дистрибуції, а також у тому, що більшість зі стрічок не відповідає вимогам масових популярних фільмів: високий бюджет, відомі елітарні актори, ефектні сцени, певна „гламурність” зображення тощо.

Натомість масовий український глядач отримує альтернативну історію, творену крізь призму інтересів Російської Федерації, що, на відміну від України, активно використовує кінематограф у цілях ідеологічної політики. Детальніше про творення міфів у просуванні ідеології, часто загрозливої для національної безпеки України, йдеться у статтях і виступах українських науковців: Андрія Смуся Про кіно В Україні як зброю масового ураження²0, Петра Кралюка про

${ }^{19} \mathrm{OOO}$ „Синебридж-Кино”, http://rsp.datagov.ru/fk/s/c66e07eca86c11deb4a112313900 ес $48 /(12.10 .2011)$.

20 А. Смусь, Про кіно в Украӥні як зброю масового ураження, [в:] Нова інформаційна ситуація та тенденції альтернативного розвитку ЗМК в Україні: Матеріали I Всеукраїнської науково-практичної конференції студентів та молодих вчених, за заг. ред. канд. філос. наук, доц. Л.В. Квасюк, Острог 2010, с. 165-167. 
фільм Тарас Бульба (Владимира Бортко)21, Дмитра Шевчука Російські історичні кіноміфри 22 . Кінопродукція російського виробництва активно культивує російські міфи в українській масовій свідомості, огорнувши всі історичні етапи від Ярослав. Тисячу років тому (Дмитра Коробкіна) до Ми з майбутнъого - 2 (Олександра Самохвалова і Бориса Ростова).

Україна ж, на жаль, активно підтримує антиукраїнський ідеологічний напрям, беручи участь у зйомках спільних російсько-українських проектів, підтримуючи створення продукції недержавною мовою та транслюючи російську продукцію, що відображає відповідну ідеологію. Наведемо приклад: Міністерство Культури України виділило на зйомки спільного фільму У суботу (Олександра Міндадзе) 13 млн. 400 тис. грн., проте в цьому проекті не був задіяний жодний з українських кіномитців ${ }^{23}$. Виділяють кошти на спільні фільми військової тематики, в яких продовжують культивувати образи радянських героїв, не надаючи можливості масовому глядачу інтерпретувати події самостійно. Візьмемо хоча б чесько-словацько-український проект Англійська полуниия (Владимира Дрги), що репрезентує глядачеві події 1968 року в Чехії і змальовує радянських солдат, як звичайних стомлених хлопчаків, що хочуть додому. Показово, що ця стрічка до масового глядача в Україні так і не потрапила.

У статті Сучасні іміджеві проекти в національному кінематографі Леся Дяк розглядає парадокс українського кінематографу, визначивши за допомогою експертного опитування фільми, що найбільше демонструють національні способи світорозуміння, світобачення і світосприйняття (Райські птахи Романа Балаяна, Біля річки Елизабет Нойман, Мелодія для шарманки Киры Муратової). 3 іншого боку, оприлюднені результати опитування, що стосується розглядуваних проблем, засвідчують, що значна частина опитаних

[...] не відносить названі фільми до національного кінематографу, пояснюючи свої відповіді тим, що автори фільмів не опираються на історичний спадок, етнічне коріння, традиції, мову24.

21 Телепередачі із циклу „Віват академія” за 2009 рік, Детальніме, http://www.oa.edu. ua/ua/media/video/2009/vivat (20.12.2011).

22 Д. Шевчук, Російські історичні кіно міфи, http://www.zgroup.com.ua/article.php? articleid=1651 (14.11.2011).

23 Р. Лебедь, Україна фінансує російські фільми, а не свої?, http://www.bbc.co.uk/ ukrainian/news/2011/06/110616_cinema_ukraine_russia_rl.shtml (18.10.2011).

24 Л. Дяк, Сучасні іміджеві проекти в національному кінематографі, [в:] Нова інформачійна ситуація та тенденції альтернативного розвитку ЗМК в Украйні: збірник тез доповідей I Всеукраїнської науково-практичної конференції студентів та молодих вчених, http:// www.oa. edu.ua/doc/zbirnik.pdf (22.11.2011). 
Отже, сучасна урядова політика в гуманітарній сфері нівелює можливості кінематографу в потребі держави формувати національну ідентичність українців. Творення україномовних фільмів державними кіностудіями не підтримується чіткою системою дистрибуції, а створені в Україні касові фільми не спираються на українські традиції, цінності і мову, тому не $є$ їх трансляторами. Зарубіжні ігрові фільми часто культивують загрозливу ідеологію. Кінематограф є важливим інструментом формування ідентичностей: наслідком цього є процес конструювання розірваної радянсько-російсько-української ідентичності. Така ситуація вимагає обов'язкової переоцінки підходів до державного кінематографу з боку української влади. 